\title{
Can Suboptimal Visual Environments Negatively Affect Children's Cognitive Development?
}

\author{
Alexandros A. Lavdas ${ }^{1,2}$ and Nikos A. Salingaros ${ }^{3, *}$ (D) \\ 1 Eurac Research, Institute for Biomedicine, Affiliated Institute of the University of Lübeck, Via Galvani 31, \\ 39100 Bolzano, Italy; a_lavdas@yahoo.com \\ 2 The Human Architecture \& Planning Institute, Inc., 43 Bradford St., Concord, MA 01742, USA \\ 3 Departments of Mathematics and Architecture, The University of Texas, San Antonio, TX 78249, USA \\ * Correspondence: salingar@gmail.com
}

Citation: Lavdas, A.A.; Salingaros,

N.A. Can Suboptimal Visual

Environments Negatively Affect

Children's Cognitive Development?.

Challenges 2021, 12, 28. https://

doi.org/10.3390/challe12020028

Academic Editors: Susan L. Prescott, Ganesa R. Wegienka, Nicole Redvers and Jake Robinson

Received: 30 September 2021

Accepted: 6 November 2021

Published: 9 November 2021

Publisher's Note: MDPI stays neutral with regard to jurisdictional claims in published maps and institutional affiliations.

Copyright: (c) 2021 by the authors. Licensee MDPI, Basel, Switzerland. This article is an open access article distributed under the terms and conditions of the Creative Commons Attribution (CC BY) license (https:/ / creativecommons.org/licenses/by/ $4.0 /)$.

\begin{abstract}
There are indications that children born during the period of COVID-19 lockdown have cognitive development issues, without having been affected by the virus. We discuss here the idea that environmental deprivation —and, especially, the lack of appropriate visual stimulation-might be one source of these defects. This thought is in line with previous findings in children brought up in orphanages with poor environmental stimulation, hypothesizing that the minimalist architectural style prevailing for the last several decades is among the potential contributing factors. The process of eliminating organized complexity characteristic of organic forms may prove to be detrimental for humanity's future, providing suboptimal environmental stimulation and opportunities for interaction during the critical stages of brain development.
\end{abstract}

Keywords: architecture; artificial intelligence; biophilia; children; complexity; COVID-19; deep symmetry; fractals; intelligence; modernism; neuroscience

\section{Introduction}

For most, the following was a surprising finding: a recent American study indicated that children born during the COVID-19 pandemic have significantly reduced motor, verbal, and overall cognitive performance compared to those born before the pandemic [1], with scores showing a significant reduction on the Early Learning Composite (ELC). While the above study is still under review, another supporting study has appeared [2]. These are genetically normal children that had not been infected, so the discussion about adults who have recovered from COVID-19 with their IQ negatively impacted [3] is completely separate. Any effects giving rise to reduced cognitive performance are independent of the virus itself. This is the reason why the physical surrounding environment is a principal suspect.

The purpose of this essay is to encourage directions for future research that medical professionals and researchers from related disciplines will most likely undertake in response to such findings. We should emphasize that this is a synthesis rather than a research study presenting original data by the authors. The central question is how far visual information input shapes human physiology and brain development. Beyond the obvious environmental factors to be investigated, research should not neglect the effects of the visual information (colors and patterns embedded in the walls) and geometry of the environment. Those influences on mood and perception, and cognitive development in particular, have been underestimated if not outright ignored during the past hundred years. This neglect is in large part due to the architectural tradition of the 20th and 21st centuries, in which complex visual information in the surroundings was minimized for stylistic reasons. It has been widely assumed that this was a good thing, hence placing architectural style beyond suspicion when something goes wrong.

Readers need to be reminded that the informational environment is crucial to infant development. Consequently, another result of this investigation exposes a disconnect 
between two disciplines: architecture and medicine. In private communications to leading architectural academics, one of the authors (N.A.S.) has repeatedly attempted to convey the seriousness of the above results on infant cognitive development. The responses were disappointing, in essence claiming that this topic is "not relevant to architecture". Based on this history, it is imperative to expose this alarming difference of opinion, which the general public certainly does not suspect.

The present article therefore proposes a paradigm shift in the way that society conceives of and shapes the built environment. Architectural style that contradicts scientific findings is condemned despite its support from the building and design professions. For more than one century, architects and the construction industry have imposed their design preferences on users while ignoring the effects of those buildings on people. Existing results from widely ranging topics in applied science are pulled together here into an argument about how geometry impacts the human brain directly. An unexpected development is that Artificial Intelligence (AI) provides valuable insight-even if it is only through analogy-into how the physical environment shapes an infant's cognitive abilities.

\section{Can Sensory Deprivation Impact Children's Cognitive Development? Evidence from the Neuroscience of Brain Development}

What accounts for this deficit in the measured children's cognitive development? The pandemic's unprecedented period of indoor isolation is most likely to have played a key role. Despite the limitations of the two cited studies [1,2], serious questions are raised.

There exist compelling human data from children housed in Romanian orphanages during the reign of the communist dictator Ceausescu [4,5]. Their life in these institutions was characterized by severe sensory deprivation, as well as social isolation and stress (in such abysmal conditions the architecture of the orphanages probably did not play the major role). The children were eventually adopted at various stages of their development (after the fall of the regime) and were studied as adults, several years later, when comparisons were made with people that had spent a similar period of time in UK orphanages. Despite environmental enrichment in the intervening years spent after being adopted, infant environmental deprivation was associated with lower total brain volume in a dose-dependent way, and also, regionally specific effects were seen. In addition, a lower intelligence quotient and more attention deficit/hyperactivity disorder symptoms were observed in their population.

Donald $\mathrm{O}$. Hebb, the father of modern neuropsychology, already postulated in the 1940 s that an environment enriched with ordered complexity enhanced animal (and human) intelligence. A major validation came in the 1960s, when environmental enrichment was observed to lead to structural changes in the brains of animals [6].

It is known that isolation in minimalist, sensory-depriving environments affects cognitive development negatively and can appreciably reduce the size of animals' brains [7]. In one experiment, the brains of trout bred in informationally distinct environments had markedly different sizes. The smallest trout's brain was measured for the group of fish raised in minimalist tanks; next larger were those raised in a more naturalistic environment, for example, a tank that included a floor of pebbles; and the largest brain size was for trout caught in the wild that are exposed to a far richer experiential and visual environment. Relative cerebellar size was significantly smaller in the fish raised in minimalist tanks (and similar in the other two groups), with differences also noted in locomotory behavior, which correlates strongly with cerebellar function [8].

In related experiments on mice, a significantly larger number of neurons were found in the hippocampus of those animals raised in an architecturally enriched environment versus those raised in featureless cages [9]. Separate studies found a conspicuously accelerated development of the visual system in the brains of mice raised in architecturally enhanced versus minimalist environments [10].

In general, robust data from animal experiments indicate the effects of visual deprivation at various levels. For example, monocular visual deprivation during development in cats leads to structural and physiological [11-13] defects in the visual system that are 
not fully reversible. Presenting stimuli of one type alone, such as only vertically oriented lines [14], the visual system becomes relatively insensitive to stimuli at the nonexposed orientations. Austin Riesen was a pioneer in these investigations on the functional level, using newborn chimpanzees (our closest relatives), at first raising them in full darkness, and reporting that after two years, the animals were visually impaired, effectively blind though not physically blind, with a difficult and protracted adjustment period to light conditions [15]. In further experiments, animals were raised under a diffuse, unstructured light, and with varying degrees of pattern stimulation, giving different results on sensory handicaps depending on the type of stimulation [16]. Many other investigators have approached this issue in the last several decades [17]; what is relevant here is the direct influence of environmental information on the development of the neural system.

The human infant develops its cognitive abilities, and hence its capacity to comprehend and interpret the world, through establishing and refining new neurological connections. At birth, a baby's brain is only $25 \%$ of its adult size. While the number of neurons does not change substantially, the synapses begin to multiply rapidly. Then, after the age of 2, synaptic pruning starts: some neuronal connections are consolidated, and their synapses preserved and strengthened, while other early synapses are eliminated. This selective pruning is influenced by neuronal activity by way of positive feedback. Sensory input from environmental complexity essentially shapes the synaptic profile: those that are used repeatedly become permanent, and the connections they mediate are strengthened, while those that are not used perish in a process of activity-dependent synaptic remodeling [18-20].

In addition, the hippocampus, which is an area related to spatial navigation and episodic memory (among other functions), continues to generate new neurons into adulthood and old age, and there is overwhelming evidence from rodent experiments that environmental enrichment directly influences this process [21,22]. The data available in humans also support the existence of adult hippocampal neurogenesis [23]. Correlation of the extent of this phenomenon with environmental factors is difficult to establish in humans, but parameters have been investigated through non-invasive methods. For example, there are findings of significantly larger hippocampal gray matter in licensed London taxi drivers when compared to control subjects [24] and an increase in un-licensed taxi drivers trained to become licensed [25], which correlates with a spatial navigation expertise and memory of the city.

Another example concerns differences in the hippocampal formation, with higher volumes in adolescents exclusively brought up in rural regions as compared to those exclusively brought up in cities. Moreover, the gray matter volume in the cluster of the left hippocampal formation was positively correlated to performance in a spatial processing task, with those with a rural upbringing scoring higher than those with an urban upbringing [26]. It is possible that this is more an effect of the fact that rural regions offer more opportunities for spatial exploration than of the type of visual stimulation per se that they offer (in keeping with the results from the taxi drivers). Nonetheless, these findings present evidence of a direct correlation between the exposure of the developing individual to environmental complexity and structural and functional changes in the brain. It is noteworthy that differences in the amygdala, a structure with a central role in responses to stressful situations, were also demonstrated in this study, as had been in a previous study of older healthy adults [27]. Even though outside the scope of the present essay, there are obvious implications for maintaining healthy cognitive function in the elderly.

Intelligence in humans and animals emerges from active perception and sensory interaction and integration with the world. Infants are instantly attracted to faces, and within a week after birth, they tend to look longer at attractive faces [28], an effect that generalizes across race, sex, and age by 6 months [29]. This finding is particularly intriguing, as it reveals the early emergence of a capability that is of much higher resolution than simply spotting two eyes and a mouth (an abstract facial pattern). Healthy growth requires an appropriate sensory exposure to a type of organized complexity for which we seem to 
be tuned. The brain, as we know from observations in adults, interprets visual information using analysis of statistical patterns of spatial frequencies [30]. Furthermore, functional MRI shows that the processing of recursive (fractal) forms recruits different resources from the processing of non-recursive forms and, remarkably, that it enlists the default mode network, a functional brain network known to be involved in the processing of internal information [31,32].

This type of very precisely tuned complex informational input is exactly what applications of aesthetic formalism in design have removed. Therefore, despite assertions to the contrary, the degree of visual complexity and organization of immediate environments is highly relevant to the architecture profession.

\section{Architecture That Ignores the Mathematics of Life-And Psychological Health}

In recent years, many studies have focused on the potential physiological impact of the visual organization of our surroundings, either natural or artificial [33-36], with "naturalness" at the center of this attention [37]. Natural surroundings are shown to have beneficial effects on mood and stress [38,39], improving concentration and working memory [40-44], self-perceived health [45], and self-esteem [38,46]. A reduction in selfreported rumination and neural activity in the subgenual prefrontal cortex associated with a self-focused behavioral withdrawal in healthy and depressed individuals is also reported [47]. Other intriguing findings include the association of exposure to natural forms with a reduction in criminal behavior [48,49], with a delay in median age at menopause [50], and even with improved recovery from surgery [51]. Fractals, i.e., complex structures that have components at many different smaller scales down to the details (the opposite of minimalist and smooth), are an important component of these effects but do not represent the full range of connective qualities [52].

We now understand that the visual features responsible for positive emotional responses are to be found not only in nature but also in artificial environments that are known to be directly beneficial [36,53-57]. Industrial-modernist architecture has to be strongly criticized for removing these visual and organizational features from our environment. The problem is all the more acute because this building style enjoys a century-long hegemony by being linked to economic development and technological progress (an example of industry succeeding commercially despite negative consequences) [58]. Contradictions between architectural ideas and models established at the beginning of the 20th century, and a contemporary understanding of human health and wellbeing, create obstacles to research. As many architects are still obsessed with the idea of an "antiseptic" and relentlessly industrial technology, the building profession mostly ignores scientific advances on how humans interact with their immediate surroundings.

For example, architectural academia, the media, practitioners, and professional organizations imprudently ignored a recent worldwide effort at radical reform of architecture education. Entreaties for a new focus on the effects of the built environment on psychological health, based on medical evidence, went unheeded as immense pressure was exerted to continue the old standards [59].

Architecture in the 20th century suppressed the essential components of "biophilia" and "deep symmetry", two related concepts that describe the evolved mechanisms whereby the human mind connects to other organisms through the mathematical structure of biological forms [60-62]. Edward O. Wilson proposed biophilia to be as necessary for human health as air, food, and water. The sensory systems of animals and humans developed from interacting with other living creatures; hence, our bodies are finely tuned biophilic receptors. Deep symmetry, in turn, denotes tightly interrelated and overlapping visual complexity, such as is evident in both biological systems and highly complex artificial systems.

Laboratory experiments reveal that this topic is not a simple matter of personal aesthetic choice. Michael Mehaffy and one of the authors of this paper (N.A.S.) coined the term "symmetry deficit disorder" to denote the negative health effects of environments that lack deep symmetry [63]. This idea came from Richard Louv's term "Nature Deficit 
Disorder", which denotes the developmental problems children experience when raised detached from nature [64].

Ann Sussman finds thought-provoking evidence of mental health issues in the trio Corbusier, Gropius, and Mies (pioneers of modernist architecture), postulating signs of Autism Spectrum Disorder (ASD) and Post-Traumatic Stress Disorder (PTSD) to explain diminished ability to process complex visual stimuli-including an aversion to face-like symmetries that babies crave $[56,65]$. Being driven by a physiological avoidance of mathematical complexity could explain, in part, the origins of minimalist design. That style switches the mechanisms for interacting with biological and natural forms to give preference to emptiness. Interestingly, decreased synaptic pruning has been reported in the autopsies of children that had suffered from ASD [66,67]. This anatomical feature was observed in the superior middle temporal lobe, an area implicated in ASD both through functional imaging and histological studies [68-70], as well as because of this area's participation in brain networks involved in language, social and speech perception, auditory and visual processing, and understanding of intentions [71,72]. It is possible that exposing children to minimalist environments during the time of synaptic pruning, from age 2 onwards, compromises this essential process, as already discussed.

\section{Collective Amnesia about the Child's Realm}

The child's world focuses on an intimate spectrum of sizes that is much smaller than that of an adult. The easiest place to see this is in active play spaces created by the children themselves. Andrew Crompton analyzed the fractal nature of the everyday environment [73]. Children love to play in alcoves, under tables, in spaces within spaces, and in cubbies that correspond to their own physical size. This tells us something fundamental about how children experience and perceive the world and, conversely, how large dimensions and spaces do not fit the child's psyche. As early as age 3, children have been shown to have a preference for fractal patterns; in keeping with findings in adults, higher complexity is preferable for exact fractals and low-to-moderate complexity for statistical fractals [74].

The same fractal geometric qualities attract children to enjoy the experience of complex spaces outdoors, and they did construct such habitats-for example, cubby houses and tree houses suited to their own scale-in past ages when children were permitted to roam freely outside. Fractal articulations found in older urban fabric disappeared from the overscale, sterile world of industrial-modernist sheer walls and large abrupt structures. One wonders, however, why architects starting in the early 20th century ignored the child's physical scale range in creating the built environment, convincing society to consent to this drastic change. Uncompromising stylistic dictates suddenly eliminated the fractality observed in the millennia of traditional construction [52-57].

Human beings do change their habits under changing circumstances; that is how humankind was able to evolve to take advantage and adapt to its environment. Our evolution is determined by our ability to integrate into the environment using our senses. Those of our animal ancestors that did not adapt to their changing environment-and to new opportunities within that environment-did not survive to procreate. The evolution of the human species changed radically, however, when social evolution became more influential than biological evolution. Societies survive or not based on their societal habits, rituals, and superstructure. Mechanisms override environmental signals that a society experiences, which have been critical to its evolutionary survival. Those conditioning forces correspond to belief systems that are often shaped by cognitive dissonance, and which are manifested by belief systems that take precedence over hard evidence that our intelligence and perceptual systems pick up.

Humans live in social groups defined in a nested hierarchy of sizes. Supporting a social group's cultural norm while suppressing our individual reactions is a tried-and-true survival method on the level of a society [75]. However, when this mechanism is at odds with biology, it can threaten other components of species survival, such as the wellbeing 
and healthy development of children. If there is indeed an effect on the level of synaptic refinement of developing children, as discussed above, it is conceivable that it could lead to a disastrous positive feedback loop in the long run, as more people could emerge with such specific, autistic-like impairments, ever more ready to design and/or accept minimalist environments. This could be seen as an expression of a Baldwin/Piagetian effect, in a negative form [76].

Over decades, many critics of architecture have called for reform, pleading for a more humane approach in how we build our world (see Curl [77] for a recent and comprehensive criticism of the industrial-modernist building style). However, we face a very powerful obstacle: an "architecture-industrial complex" that, in the manner of a system focused on preserving its legitimacy, effortlessly brushes off every challenge to its economic and intellectual dominance. To make things worse, the contemporary building industry's vast economic power manipulates the media to draw attention away from warnings such as those presented here $[58,77]$.

Too often, healthy design concepts are co-opted; that is, they are not honestly applied, but the terms are simply being picked (without paying attention to their rationale) as useful buzzwords for continuing business as usual. Architectural culture has learned to apply band-aid solutions that provide the superficial impression of improvement, while continuing to use its preferred design typologies currently being questioned by new scientific research. Ideology and short-term profit override scientific evidence, while an extensive public relations network covers up this action.

\section{Discussion}

This essay postulates that humans shape their environment through imposing organized complexity in the form of color, detail, fractal shapes, mural paintings, and ornamentation. Projecting rich yet organized informational complexity onto the artificial environment mimics the visual input required both to develop our mind as infants and to nourish our need for informational complexity for which human evolution equipped us-to ensure our survival. One could add that humans, and other animals before us, evolved what we now call "intelligence" as a tool to interpret the complexity of the natural environment.

There is a lesson here for our society: humans, especially children, need informationrich sensory environments, and they suffer when forced to spend long periods in minimalist ones. The 1994 Carnegie Task Force Report warned that children raised in experientially poor environments suffer permanent setbacks as compared to those raised in richer, more enhanced environments [78]. This initiative was in line with the Head Start Program begun several decades earlier in the US. Characteristically, the architecture profession did not react to this warning but continued to impose its ideologically based minimalist styles, even on school buildings [79].

Any chronic inadequacies with domestic space became acute with lockdown during the recent COVID-19 pandemic [80]. As the rearing environment dramatically impacts brain growth in children, such a crisis turned into a massive (but unplanned) experiment because normally prevalent sources of visual complexity — such as nature, day-care, school, visits, etc.- can no longer make up for any lack of stimulation in the child's living spaces. (A consideration that would explain why intelligence decrease occurred now, rather than after the industrial-minimalist style was introduced in the 1920s-but can we be sure it did not? It is quite possible that an effect on child development might have been noticed in segments of the population during the past century, yet we have no data to even conjecture on this possibility.) This news about infant development comes at the very moment that minimalist design is the height of fashion in the architecture profession, promoted relentlessly in architecture schools, on magazine covers and websites, and by critics and connoisseurs. However, are these kinds of environments lacking mathematical information actually detrimental to the human brain, especially that of children? 
Much attention has focused recently on the harmful effects of social media and smart phones, especially on children and teens [81]. While this component of environmental exposure is significant, there are no data of its relevance to the group of children studied in the survey reported at the beginning of this article [1]. Anecdotal evidence from the general population points to parents putting some video streaming on an iPad or iPhone in the crib to keep their baby occupied [82]. For decades, a simple stratagem for keeping a baby distracted is to place it in front of a television [83]. Anyone assuming this facile expedient as a solution to the problem identified in the above study (i.e., a lack of stimulation) would be wrong. The American Association of Pediatrics recommends that babies not be exposed to video screens before the age of two [84].

As an unexpected background for this discussion, Artificial Intelligence helps to clarify-through analogy-how the learning mechanism is wired in stages. Consider the ancient board game of Go popular in East Asia. This game requires very high-level conceptual skills. An astonishing win of the computer program AlphaGo over the world's human Go champion occurred in 2016 [85]. The AlphaGo software, created with the Artificial Intelligence program "DeepMind" (a London-based project), was trained on an enormous number of past games. The program was exposed to as many complex game configurations as possible-it learned the winning strategies from experience and was not directly programmed with all the number of actual moves (unlike earlier generation game-playing computer programs). In an even more impressive recent development, the latest software MuZero [86] uses a different approach, modeling aspects of the environment that are important to the decision-making process: the value, the potential policy, and the reward, in a Piagetian iterative scheme. This is not an approach that is independent of the available information; on the contrary, reinforcement learning heavily relies on the availability of such information and upon easily graspable cues on its saliency.

The infant brain also develops its cognitive abilities, hence the capacity to comprehend and interpret the world, through establishing and using the appropriate neurological connections. Healthy growth requires maximum sensory exposure to organization-training from the complexity of perceived patterns. As in the case of these AI software applications, parents cannot program all the vast amounts of information crucial to their child's mental development but have to provide input that somehow trains their infant's brain through active processing. Intelligence in humans and animals emerges from active perception and sensory interaction with the world.

Which brings us to a crucial but unexplored topic: how does one train the infant brain with complex information? Existing studies suggest that fast-moving images shown on screens are not the way to do it and may actually be causing harm [87]. That medium is generated by an industry that hires psychologists to capture an adult's or grown child's attention [88]. Since they were not meant for babies, dynamic screen images are not vetted by neurodevelopmental pediatricians to check how they might influence the highly malleable developing infant brain. Whatever is going on, the colors, designs, and rapid movement of ubiquitous videos are not specifically aimed at helping to wire the infant's brain, which does not work the same way as that of adults. Later attention problems are suspected due to such early overstimulation.

Concerned parents already know of tried-and-tested techniques for doing exactly what is required in a healthy manner, and which belong to an entirely different informational category. Pediatricians recommend that cribs be lined with bold patterns, preferably black and white, showing clear and nested symmetries $[89,90]$. The baby then spends a long time studying these static images and registering their patterns. It is necessary to provide something engaging and sufficiently complex for the baby to focus on and analyze at its leisure. Do not forget that the visual acuity of infants is several orders of magnitude less sharp than that of adults, hence the need for bold patterns. It takes on the order of one year for the baby's eyes to become fully functional.

What happens later, when the baby begins to crawl on the floor and explore the family's living space? Will it experience color, detail, material texture, and coherent 
complex patterns? Requisite visual complexity conflicts with dull gray and white vacuity, which defines our society's preferred minimalist aesthetic [80,91]. While infants have a less nuanced color perception than children who are a bit older, or adults, it seems that some innate color preferences are shown as early as 4-6 months [92]. The developmental value of color is being actively investigated, with results indicating that an appropriately dosed and harmonized (not overwhelming) presence of color may be very beneficial [93-95]. Still, architectural culture continues to ignore all such complex psychological effects.

Here is where the lesson from the AlphaGo software is highly relevant, albeit through establishing an analogy. Information documenting previous Go games had to be presented to the learning software in an appropriate and precise manner. Unless the input of the game archive matched the input format of "DeepMind" exactly, using an optimal interface for transferring information, there was no way of implementing the learning exercise. We believe there is an important point to be made: beneficial informational input to the infant mind needs to precisely match the physiological channels open for the baby's brain to receive such useful information. It follows that the infant's physical environment needs to be shaped according to medical knowledge on brain development and not by arbitrary architectural style.

Data on decreasing children's cognitive development are sufficient to trigger a paradigm shift in how we evaluate architecture. Because it flatly contradicts biophilia, some researchers now suspect that minimalist architecture interferes with a key evolutionary mechanism [31-47,55-57,60-65]. Environmental complexity and organization train the human brain, building explanatory systems to interpret those informational qualities necessary for survival-and at the same time spurring humans to represent them in everyday surroundings. This process of user embellishment is seen throughout the millennia of human existence. However, focusing on a minimalist design style has cut this feedback loop. After the AlphaGo win, the Chinese government made it a priority to spend heavily on Artificial Intelligence (AI) research (and several American AI research labs are also based in China).

\section{Conclusions}

Our future depends upon making the right choice between what to believe and what to ignore-the manner by which we escape from cognitive dissonance brought upon by, now evident, contradictions. Short-term pressures can be overwhelming, and those often favor the wrong choice $[91,96]$. Society ignores new results in applied science that might dispute standard typologies shaping the built environment, used without controversy over the past century. In addition, many practitioners in architecture and design simply continue what was set by the modernist revolution (one century ago), never questioning whether it was all such a great idea. Will people now pay attention to the visual information embedded in the environment? [97] For this reason, architectural culture today is not reacting to the alarming converging lines of evidence pointing to the deleterious effects of these practices on child development. Contemporary architectural discourse is apparently uninterested in this question.

This essay accuses the architecture profession of not paying sufficient attention to human psychological health, including children's development. Recent studies of infants born during the COVID-19 lockdown raise alarming questions about the possibility of lowered cognitive development, for whatever reason. Various arguments were collected here to point the finger at the lack of requisite visual complexity in "fashionable" industrialminimalist interiors. Will we see a generation of children with intellectual impairments? Nobody really knows. Can the medical profession and society as a whole ignore this frightening possibility and do nothing about it?

What is needed, therefore, is for other professions to step into the breach, including childhood development fields, environmental psychology, Artificial Intelligence, mathematics, neuroscience, medical science, mental health professions, political philosophy, and even physics, to demand a more human-centered focus on designing the world we 
all inhabit. It is long past time to scrap the limitations of architectural modernism and generate a new, more evidence-based architectural culture from the bottom up. Our survival and flourishing depend upon making use of science to improve humanity's prospects. It is crucial to resolve difficult conflicts between health and special interests instead of continuing to let the latter decide.

Author Contributions: Conceptualization, N.A.S.; methodology, A.A.L. and N.A.S.; formal analysis, A.A.L. and N.A.S.; investigation, A.A.L. and N.A.S.; writing-original draft preparation, N.A.S.; writing-review and editing, A.A.L. and N.A.S. All authors have read and agreed to the published version of the manuscript.

Funding: This research received no external funding.

Acknowledgments: Thanks to Michael Mehaffy and Ann Sussman for their comments on early drafts of this essay.

Conflicts of Interest: The authors declare no conflict of interest.

\section{References}

1. Deoni, S.C.; Beauchemin, J.; Volpe, A.; D'Sa, V. Resonance Consortium. Impact of the Covid-19 Pandemic on Early Child Cognitive Development: Initial Findings in a Longitudinal Observational Study of Child Health. medRxiv 2021. [CrossRef]

2. Shuffrey, L.C.; Firestein, M.R.; Kyle, M.; Fields, A.; Alcantara, C.; Amso, D.; Austin, J.; Bain, J.M.; Barbosa, J.; Bence, M.; et al. Birth during the COVID-19 pandemic, but not maternal SARS-CoV-2 infection during pregnancy, is associated with lower neurodevelopmental scores at 6-months. medRxiv 2021. [CrossRef]

3. Hampshire, A.; Trender, W.; Chamberlain, S.R.; Jolly, A.E.; Grant, J.E.; Patrick, F.; Mazibuko, N.; Williams, H.R.; Barnby, P.; Hellyer, J.M.; et al. Cognitive Deficits in People Who Have Recovered from Covid-19. Lancet EClin. Med. 2021, 39, 101044. [CrossRef]

4. $\quad$ Mackes, N.K.; Golm, D.; Sarkar, S.; Kumsta, R.; Rutter, M.; Fairchild, G.; Mehta, M.A.; Sonuga-Barke, E.J.S.; ERA Young Adult Follow-up Team. Early Childhood Deprivation Is Associated with Alterations in Adult Brain Structure Despite Subsequent Environmental Enrichment. Proc. Natl. Acad. Sci. USA 2020, 117, 641-649. [CrossRef]

5. Sonuga-Barke, E.J.S.; Kennedy, M.; Kumsta, R.; Knights, N.; Golm, D.; Rutter, M.; Maughan, B.; Schlotz, W.; Kreppner, J. Child-to-Adult Neurodevelopmental and Mental Health Trajectories after Early Life Deprivation: The Young Adult Follow-up of the Longitudinal English and Romanian Adoptees Study. Lancet 2017, 389, 1539-1548. [CrossRef]

6. Rosenzweig, M.R.; Bennett, E.L. Psychobiology of plasticity: Effects of training and experience on brain and behavior. Behav. Brain Res. 1996, 78, 57-65. Available online: https:/ / patterns.architexturez.net/doc/az-cf-172877 (accessed on 5 November 2021). [CrossRef]

7. Mehaffy, M.; Salingaros, N.A. Intelligence and the Information Environment. Metropolis, 25 February 2012. Available online: https:/ / patterns.architexturez.net/doc/az-cf-172600 (accessed on 26 August 2021).

8. Kihslinger, R.L.; Nevitt, G.A. Early rearing environment impacts cerebellar growth in juvenile salmon. J. Exp. Biol. 2006, 209, 504-509. Available online: https:/ / patterns.architexturez.net/doc/az-cf-172728 (accessed on 5 November 2021). [CrossRef]

9. Kempermann, G.; Kuhn, G.H.; Gage, F.H. More hippocampal neurons in adult mice living in an enriched environment. Nature 1997, 386, 494-495. Available online: https://patterns.architexturez.net/doc/az-cf-172602 (accessed on 5 November 2021). [CrossRef] [PubMed]

10. Sale, A.; Putignano, E.; Cancedda, L.; Landi, S.; Cirulli, F.; Berardi, N.; Maffei, L. Enriched environment and acceleration of visual system development. Neuropharmacology 2004, 47, 649-660. Available online: https:/ / patterns.architexturez.net/doc/az-cf-172878 (accessed on 5 November 2021). [CrossRef]

11. Wiesel, T.N.; Hubel, D.H. Effects of Visual Deprivation on Morphology and Physiology of Cells in the Cats Lateral Geniculate Body. J. Neurophysiol. 1963, 26, 978-993. [CrossRef] [PubMed]

12. Wiesel, T.N.; Hubel, D.H. Single-Cell Responses in Striate Cortex of Kittens Deprived of Vision in One Eye. J. Neurophysiol. 1963, 26, 1003-1017. [CrossRef]

13. Hubel, D.H.; Wiesel, T.N. The Period of Susceptibility to the Physiological Effects of Unilateral Eye Closure in Kittens. J. Physiol. 1970, 206, 419-436. [CrossRef] [PubMed]

14. Hirsch, H.V.; Spinelli, D.N. Visual Experience Modifies Distribution of Horizontally and Vertically Oriented Receptive Fields in Cats. Science 1970, 168, 869-871. [CrossRef] [PubMed]

15. Riesen, A.H. The Development of Visual Perception in Man and Chimpanzee. Science 1947, 106, 107-108. [CrossRef]

16. Riesen, A.H. Studying Perceptual Development Using the Technique of Sensory Deprivation. J. Nerv. Ment. Dis. 1961, 132, 21-25. [CrossRef]

17. Pan, Y.; Monje, M. Activity Shapes Neural Circuit Form and Function: A Historical Perspective. J. Neurosci. 2020, 40, 944-954. [CrossRef] 
18. Bourgeois, J.P.; Goldman-Rakic, P.S.; Rakic, P. Synaptogenesis in the Prefrontal Cortex of Rhesus Monkeys. Cereb. Cortex 1994, 4 , 78-96. [CrossRef] [PubMed]

19. National Research Council and Institute of Medicine; Committee on Integrating the Science of Early Childhood Development. The Developing Brain. In From Neurons to Neighborhoods: The Science of Early Childhood Development; Shonkoff, J.P., Phillips, D.A., Eds.; National Academy Press: Washington, DC, USA, 2000. [CrossRef]

20. Sakai, J. Core Concept: How Synaptic Pruning Shapes Neural Wiring during Development and, Possibly, in Disease. Proc. Natl. Acad. Sci. USA 2020, 117, 16096-16099. [CrossRef]

21. Kempermann, G.; Kuhn, H.G.; Gage, F.H. Experience-Induced Neurogenesis in the Senescent Dentate Gyrus. J. Neurosci. 1998, 18, 3206-3212. [CrossRef]

22. Kempermann, G.; Gast, D.; Gage, F.H. Neuroplasticity in Old Age: Sustained Fivefold Induction of Hippocampal Neurogenesis by Long-Term Environmental Enrichment. Ann. Neurol. 2002, 52, 135-143. [CrossRef]

23. Kempermann, G.; Gage, F.H.; Aigner, L.; Song, H.; Curtis, M.A.; Thuret, S.; Kuhn, H.G.; Jessberger, S.; Frankland, P.W.; Cameron, H.A.; et al. Human Adult Neurogenesis: Evidence and Remaining Questions. Cell Stem Cell 2018, 23, 25-30. [CrossRef] [PubMed]

24. Maguire, E.A.; Gadian, D.G.; Johnsrude, I.S.; Good, C.D.; Ashburner, J.; Frackowiak, R.S.J.; Frith, C.D. Navigation-Related Structural Change in the Hippocampi of Taxi Drivers. Proc. Natl. Acad. Sci. USA 2000, 97, 4398-4403. [CrossRef] [PubMed]

25. Woollett, K.; Maguire, E.A. Acquiring “the Knowledge” of London's Layout Drives Structural Brain Changes. Curr. Biol. 2011, 21, 2109-2114. [CrossRef] [PubMed]

26. Kuhn, S.; Banaschewski, T.; Bokde, A.L.W.; Buchel, C.; Quinlan, E.B.; Desrivieres, S.; Flor, H.; Grigis, A.; Garavan, H.; Gowland, P.; et al. Brain Structure and Habitat: Do the Brains of Our Children Tell Us Where They Have Been Brought Up? Neuroimage 2020, 222, 117225. [CrossRef] [PubMed]

27. Kuhn, S.; Duzel, S.; Eibich, P.; Krekel, C.; Wustemann, H.; Kolbe, J.; Martensson, J.; Goebel, J.; Gallinat, J.; Wagner, G.G.; et al. In Search of Features That Constitute an "Enriched Environment" in Humans: Associations between Geographical Properties and Brain Structure. Sci. Rep. 2017, 7, 11920. [CrossRef]

28. Slater, A.; Schulenburg, C.V.D.; Brown, E.; Badenoch, M. Newborn Infants Prefer Attractive Faces. Infant Behav. Dev. 1998, 345-354. [CrossRef]

29. Langlois, J.H.; Ritter, J.M.; Roggman, L.A.; Vaughn, L.S. Facial Diversity and Infant Preferences for Attractive Faces. Dev. Psychol. 1991, 27, 79-84. [CrossRef]

30. Simoncelli, E.P.; Olshausen, B.A. Natural Image Statistics and Neural Representation. Annu. Rev. Neurosci. 2001, 24, 1193-1216. [CrossRef]

31. Martins, M.J.; Fischmeister, F.P.; Puig-Waldmuller, E.; Oh, J.; Geissler, A.; Robinson, S.; Fitch, W.T.; Beisteiner, R. Fractal Image Perception Provides Novel Insights into Hierarchical Cognition. Neuroimage 2014, 96, 300-308. [CrossRef]

32. Fischmeister, F.P.; Martins, M.J.D.; Beisteiner, R.; Fitch, W.T. Self-Similarity and Recursion as Default Modes in Human Cognition. Cortex 2017, 97, 183-201. [CrossRef] [PubMed]

33. Coburn, A.; Vartanian, O.; Chatterjee, A. Buildings, Beauty, and the Brain: A Neuroscience of Architectural Experience. J. Cogn. Neurosci. 2017, 29, 1521-1531. [CrossRef]

34. Dzhambov, A.M.; Markevych, I.; Hartig, T.; Tilov, B.; Arabadzhiev, Z.; Stoyanov, D.; Gatseva, P.; Dimitrova, D.D. Multiple Pathways Link Urban Green- and Bluespace to Mental Health in Young Adults. Environ. Res. 2018, 166, 223-233. [CrossRef] [PubMed]

35. Hartig, T. Green Space, Psychological Restoration, and Health Inequality. Lancet 2008, 372, 1614-1615. [CrossRef]

36. Joye, Y. Architectural Lessons from Environmental Psychology: The Case of Biophilic Architecture. Rev. Gen. Psychol. 2007, 11, 305-328. [CrossRef]

37. Bowler, D.E.; Buyung-Ali, L.M.; Knight, T.M.; Pullin, A.S. A Systematic Review of Evidence for the Added Benefits to Health of Exposure to Natural Environments. BMC Public Health 2010, 10, 456. [CrossRef] [PubMed]

38. Barton, J.; Pretty, J. What Is the Best Dose of Nature and Green Exercise for Improving Mental Health? A Multi-Study Analysis. Environ. Sci. Technol. 2010, 44, 3947-3955. [CrossRef] [PubMed]

39. Valtchanov, D.; Barton, K.R.; Ellard, C. Restorative Effects of Virtual Nature Settings. Cyberpsychol. Behav. Soc. Netw. 2010, 13, 503-512. [CrossRef]

40. Berman, M.G.; Jonides, J.; Kaplan, S. The Cognitive Benefits of Interacting with Nature. Psychol. Sci. 2008, 19, 1207-1212. [CrossRef]

41. Berman, M.G.; Kross, E.; Krpan, K.M.; Askren, M.K.; Burson, A.; Deldin, P.J.; Kaplan, S.; Sherdell, L.; Gotlib, I.H.; Jonides, J. Interacting with Nature Improves Cognition and Affect for Individuals with Depression. J. Affect. Disord. 2012, 140, $300-305$. [CrossRef]

42. Berto, R. Exposure to Restorative Environments Helps Restore Attentional Capacity. J. Environ. Psychol. 2005, 25, 249-259. [CrossRef]

43. Bratman, G.N.; Daily, G.C.; Levy, B.J.; Gross, J.J. The Benefits of Nature Experience: Improved Affect and Cognition. Landsc. Urban Plan. 2015, 138, 41-50. [CrossRef]

44. Kaplan, S. The Restorative Benefits of Nature-Toward an Integrative Framework. J. Environ. Psychol. 1995, 15, 169-182. [CrossRef] 
45. Kardan, O.; Gozdyra, P.; Misic, B.; Moola, F.; Palmer, L.J.; Paus, T.; Berman, M.G. Neighborhood Greenspace and Health in a Large Urban Center. Sci. Rep. 2015, 5, 11610. [CrossRef] [PubMed]

46. Pretty, J.; Peacock, J.; Hine, R.; Sellens, M.; South, N.; Griffin, M. Green Exercise in the UK Countryside: Effects on Health and Psychological Well-Being, and Implications for Policy and Planning. J. Environ. Plan. Manag. 2007, 50, 211-231. [CrossRef]

47. Bratman, G.N.; Hamilton, J.P.; Hahn, K.S.; Daily, G.C.; Gross, J.J. Nature Experience Reduces Rumination and Subgenual Prefrontal Cortex Activation. Proc. Natl. Acad. Sci. USA 2015, 112, 8567-8572. [CrossRef] [PubMed]

48. Kuo, F.E.; Sullivan, W.C. Environment and Crime in the Inner City-Does Vegetation Reduce Crime? Environ. Behav. 2001, 33, 343-367. [CrossRef]

49. Kuo, F.E.; Sullivan, W.C. Aggression and Violence in the Inner City-Effects of Environment via Mental Fatigue. Environ. Behav. 2001, 33, 543-571. [CrossRef]

50. Triebner, K.; Markevych, I.; Hustad, S.; Benediktsdottir, B.; Forsberg, B.; Franklin, K.A.; Gullon Blanco, J.A.; Holm, M.; Jaquemin, B.; Jarvis, D.; et al. Residential Surrounding Greenspace and Age at Menopause: A 20-Year European Study (Ecrhs). Environ. Int. 2019, 132, 105088. [CrossRef]

51. Ulrich, R.S. View through a Window May Influence Recovery from Surgery. Science 1984, 224, 417-419. [CrossRef]

52. Salingaros, N. Unified Architectural Theory: Form, Language, Complexity: A Companion to Christopher Alexander's "the Phenomenon of Life: The Nature of Order, Book 1"; Sustasis Foundation: Portland, OR, USA, 2013.

53. Salingaros, N. Fractal Art and Architecture Reduce Physiological Stress. J. Biourbanism. 2012, 2, 11-28. Available online: https:/ / patterns.architexturez.net/system/files/jbu-ii-2012-2_nikos-a-salingaros.pdf (accessed on 5 November 2021).

54. Salingaros, N. The Sensory Value of Ornament. Commun. Cogn. 2003, 36, 331-351. Available online: https://philarchive.org/ archive/SALTSV-2 (accessed on 5 November 2021).

55. Taylor, R.P. Reduction of Physiological Stress Using Fractal Art and Architecture. Leonardo 2006, 39, 245-251. Available online: https:/ / citeseerx.ist.psu.edu/viewdoc/download?doi=10.1.1.741.8120\&rep=rep1\&type=pdf (accessed on 5 November 2021). [CrossRef]

56. Sussman, A.; Hollander, J.B. Cognitive Architecture: Designing for How We Respond to the Built Environment, 2nd ed.; Routledge: New York, NY, USA, 2021. [CrossRef]

57. Ruggles, D.H. Beauty, Neuroscience, and Architecture: Timeless Patterns and Their Impact on Our Well-Being; Fibonacci Press: Denver, CO, USA, 2018.

58. Buchanan, P. The Big Rethink, Parts 1-12. The Architectural Review, 2011-2013. Available online: https://www.architecturalreview.com/archive/campaigns/the-big-rethink (accessed on 5 November 2021).

59. Salingaros, N.A. (Ed.) Two Series of Essays on Architectural Education. Architexturez Imprints. 2020. Available online: https: / / patterns.architexturez.net/doc/az-cf-193386 (accessed on 5 November 2021).

60. Browning, W.D.; Ryan, C.O.; Clancy, J.O. 14 Patterns of Biophilic Design: Improving Health and Well-Being in the Built Environment; Terrapin Bright Green LLC: New York, NY, USA, 2014. Available online: https:/ / www.terrapinbrightgreen.com/reports/14 -patterns / (accessed on 5 November 2021).

61. Salingaros, N.A. Biophilia and Healing Environments; Terrapin Bright Green LLC: New York, NY, USA; Levellers Press: Amherst, MA, USA, 2015. Available online: https://www.terrapinbrightgreen.com/report/biophilia-healing-environments/ (accessed on 5 November 2021).

62. Salingaros, N.A. The Biophilic Healing Index Predicts Effects of the Built Environment on Our Wellbeing. J. Biourbanism 2019, 8 , 13-34. Available online: https:/ / patterns.architexturez.net/doc/az-cf-193195 (accessed on 5 November 2021).

63. Mehaffy, M.W.; Salingaros, N.A. The Surprisingly Important Role of Symmetry in Healthy Places. Planetizen. 8 March 2021. Available online: https:/ / www.planetizen.com/features/112503-surprisingly-important-role-symmetry-healthy-places (accessed on 5 November 2021).

64. McKivigan, M.S. Nature Deficit Disorder Is Really a Thing. New York Times. 23 June 2020. Available online: https:/ /www.nytimes. com/2020/06/23/parenting/nature-health-benefits-coronavirus-outdoors.html (accessed on 5 November 2021).

65. Sussman, A. What Neuroscience Says About Modern Architecture Approach. ArchDaily. 18 September 2020. Available online: https: //www.archdaily.com/947890/what-neuroscience-says-about-modern-architecture-approach (accessed on 5 November 2021).

66. Hutsler, J.J.; Zhang, H. Increased Dendritic Spine Densities on Cortical Projection Neurons in Autism Spectrum Disorders. Brain Res. 2010, 1309, 83-94. [CrossRef] [PubMed]

67. Tang, G.; Gudsnuk, K.; Kuo, S.H.; Cotrina, M.L.; Rosoklija, G.; Sosunov, A.; Sonders, M.S.; Kanter, E.; Castagna, C.; Yamamoto, A.; et al. Loss of Motor-Dependent Macroautophagy Causes Autistic-Like Synaptic Pruning Deficits. Neuron 2014, 83, 1131-1143. [CrossRef] [PubMed]

68. Garbett, K.; Ebert, P.J.; Mitchell, A.; Lintas, C.; Manzi, B.; Mirnics, K.; Persico, A.M. Immune Transcriptome Alterations in the Temporal Cortex of Subjects with Autism. Neurobiol. Dis. 2008, 30, 303-311. [CrossRef]

69. Voineagu, I.; Wang, X.; Johnston, P.; Lowe, J.K.; Tian, Y.; Horvath, S.; Mill, J.; Cantor, R.M.; Blencowe, B.J.; Geschwind, D.H. Transcriptomic Analysis of Autistic Brain Reveals Convergent Molecular Pathology. Nature 2011, 474, 380-384. [CrossRef] [PubMed]

70. Shih, P.; Keehn, B.; Oram, J.K.; Leyden, K.M.; Keown, C.L.; Muller, R.A. Functional Differentiation of Posterior Superior Temporal Sulcus in Autism: A Functional Connectivity Magnetic Resonance Imaging Study. Biol. Psychiatry 2011, 70, 270-277. [CrossRef] 
71. Redcay, E. The Superior Temporal Sulcus Performs a Common Function for Social and Speech Perception: Implications for the Emergence of Autism. Neurosci. Biobehav. Rev. 2008, 32, 123-142. [CrossRef]

72. Zahn, R.; Moll, J.; Krueger, F.; Huey, E.D.; Garrido, G.; Grafman, J. Social Concepts Are Represented in the Superior Anterior Temporal Cortex. Proc. Natl. Acad. Sci. USA 2007, 104, 6430-6435. [CrossRef]

73. Crompton, A. The Fractal Nature of the Everyday Environment. Environ. Plan. B Plan. Des. 2001, 28, 243-254. [CrossRef]

74. Robles, K.E.; Liaw, N.A.; Taylor, R.P.; Baldwin, D.A.; Sereno, M.E. A Shared Fractal Aesthetic across Development. Hum. Soc. Sci. Commun. 2020, 7, 158. [CrossRef]

75. Richerson, P.J.; Boyd, R. Not by Genes Alone: How Culture Transformed Human Evolution; University of Chicago Press: Chicago, IL, USA, 2005.

76. Burman, J.T. Updating the Baldwin Effect. The Biological Levels behind Piaget's New Theory. New Ideas Psychol. 2013, 363-373. [CrossRef]

77. Curl, J.S. Making Dystopia: The Strange Rise and Survival of Architectural Barbarism; Oxford University Press: Oxford, UK, 2018.

78. Levine, M.H.; Smith, S.V. Starting Points: Meeting the Needs of Our Youngest Children; Abridged Version; Carnegie Corporation: New York, NY, USA, 1994. Available online: https:/ / patterns.architexturez.net/doc/az-cf-172876 (accessed on 8 November 2021).

79. Lippman, P.C. Evidence-Based Design of Elementary and Secondary Schools; John Wiley: Hoboken, NJ, USA, 2010.

80. Aresta, M.; Salingaros, N.A. The Importance of Domestic Space in the Times of COVID-19. Challenges 2021, 12, 27. [CrossRef]

81. Ruder, D.B. Screen Time and the Brain: Digital devices can interfere with everything from sleep to creativity. Harvard Medical School. 19 June 2019. Available online: https:/ / hms.harvard.edu/news/screen-time-brain (accessed on 26 August 2021).

82. Anderson, J. A study of kids' screen time explains the vicious cycle that makes parents unable to say no. Quartz. 1 August 2017. Available online: https: / / qz.com/1042581/a-study-of-kids-screen-time-explains-the-vicious-cycle-that-makes-parents-unableto-say-no/ (accessed on 5 November 2021).

83. Beyens, I.; Eggermont, S. Putting Young Children in Front of the Television: Antecedents and Outcomes of Parents' Use of Television as a Babysitter. Commun. Q. 2014, 62, 57-74. [CrossRef]

84. Council on Communications and Media. Media and Young Minds. Pediatrics 2016, 138, e20162591. [CrossRef]

85. Alpha Go Website. Deep Mind Research. 2021. Available online: https://deepmind.com/research/case-studies/alphago-thestory-so-far (accessed on 26 August 2021).

86. Schrittwieser, J.; Antonoglou, I.; Hubert, T.; Simonyan, K.; Sifre, L.; Schmitt, S.; Guez, A.; Lockhart, E.; Hassabis, D.; Graepel, T.; et al. Mastering Atari, Go, chess and shogi by planning with a learned model. Nature 2020, 588, 604-609. [CrossRef]

87. Hutton, J.S.; Dudley, J.; Horowitz-Kraus, T.; DeWitt, T.; Holland, S.K. Associations between Screen-Based Media Use and Brain White Matter Integrity in Preschool-Aged Children. JAMA Pediatr. 2020, 174, e193869. [CrossRef] [PubMed]

88. McCarthy, C. Unhealthy Video Gaming: What Parents Can Do to Prevent It. HealthyChildren.org. 28 October 2020. Available online: https://www.healthychildren.org/English/family-life/Media/Pages/Unhealthy-Video-Gaming.aspx (accessed on 5 November 2021).

89. HuggaMind. Infant Brain Stimulation. 2014. Available online: http://www.huggamind.com/highcontrast.php (accessed on 5 November 2021).

90. Tiny Love. The Advantages of Black \& White in Developing Newborns' Vision. 2021. Available online: https:/ / www.tinylove. com/us_en/articles/newborn-development (accessed on 5 November 2021).

91. Salingaros, N.A. A Theory of Architecture, 2nd ed.; Sustasis Press: Portland, OR, USA, 2014.

92. Skelton, A.E.; Franklin, A. Infants look longer at colors that adults like when colors are highly saturated. Psychon. Bull. Rev. 2020, 27, 78-85. [CrossRef] [PubMed]

93. Tarr, P. Consider the Walls. Beyond the Journal: Young Children on the Web. 1-5 May 2004. Available online: https://coursemedia. erikson.edu/eriksononline/CPC/2014_2015/Module1/Documents /Environments /ConsidertheWalls_Journal_article.pdf (accessed on 5 November 2021).

94. Fisher, A.V.; Godwin, K.E.; Seltman, H. Visual environment, attention allocation, and learning in young children: When too much of a good thing may be bad. Psychol. Sci. 2014, 25, 1362-1370. [CrossRef]

95. Stern-Ellran, K.; Zilcha-Mano, S.; Sebba, R.; Levit-Binnun, N. Disruptive Effects of Colorful vs. Non-colorful Play Area on Structured Play-A Pilot Study with Preschoolers. Front. Psychol. 2016, 7, 1661. [CrossRef] [PubMed]

96. Mehaffy, M.; Salingaros, N. A Vision for Architecture as More Than the Sum of Its Parts: How Modernist Fundamentalism Degrades the Human and Natural Environment. On The Commons. 11 November 2013. Available online: http:// www.onthecommons.org/magazine/vision-architecture-more-sum-its-parts\#sthash.v1iaLQW4.mQyMh2Cg.dpbs (accessed on 5 November 2021).

97. Mehaffy, M.; Salingaros, N. Symmetry in architecture: Toward an overdue reassessment. Symmetry Cult. Sci. 2021, 32, 311-343. Available online: https:/ /journal-scs.symmetry.hu/abstract/?pid=895 (accessed on 5 November 2021). [CrossRef] 